Japanese Research in Business History 2005 | 22

\title{
The Establishment of Hitachi, Ltd
}

\author{
Hidetatsu SATOH \\ Aichi Sangyo University
}

$\mathrm{H}$

ITACHI, LTD., which as of March 2005 reported global consolidated sales of over $¥ 9,027$ billion, and 347,424 employees $^{1}$, is the largest electrical company in Japan, and among the largest in the world. It was founded in 1910, and incorporated in 1920 .

The pre-establishment history of Hitachi goes back to 1905, when Fusanosuke Kuhara ${ }^{2}$, one of the three co-founders and proprietors of Fujitagumi \& Co., left that company, independently purchased the Akazawa Copper $\mathrm{Mine}^{3}$ in Ibaraki Prefecture, and renaming it the

\footnotetext{
1. "Kaisha gaiyō" [Company outline] on the Hitachi, Ltd. website: http:// www.hitachi.co.jp/ (June 23, 2005)

2. For the career of Fusanosuke Kuhara see, for example: (1) Tsunekichi Baba, Gendai jinbutsu hyōron [Contemporary who's who] (Tokyo: Chuo Koron, 1930); (2) Kazuyoshi Yamazaki, Kuhara Fusanosuke [Fusanosuke Kuhara] (Tōkai Shuppansha, 1939); (3) Kuhara Fusanosuke-Ō Denki Hensankai [Editorial Committee for the Biography of Fusanosuke Kuhara], eds., Kuhara Fusanosuke [Fusanosuke Kuhara] (Nippon Mining Co., Ltd., 1970); (4) Tsunehiko Yui, Atsushi Migami, Yōichi Kobayakawa and Masaru Udagawa, Nihon no Kigyōka (2) [Entrepreneurs of Japan (2)] (Tokyo: Yuhikaku, 1978); (5) Jirō Yonemoto, Denki kuhara fusanosuke-ō wo kataru [Narrated biography of Fusanosuke Kuhara],(Libre, 1991) (hereafter referred to as Denki); (6) Hidetatsu Satoh, "Kuhara fusanosuke ron" [On Fusanosuke Kuhara], Aichi Sangyo University Business Research Center, Aisandai Keiei Ronsō, 8, 2005.

3. The origins of the Akazawa Copper Mine go back to an official order in 1591 from
} 
Hitachi Mine, started operating it as the Hitachi Mine of Kuhara Mining (the Japan Energy Corporation of today). In 1912 he reorganized Kuhara Mining into the Kuhara Mining Company, Ltd., with its Head Office in Osaka. Kuhara had worked as Office Manager at the Kosaka Mine Fujitagumi \& Co. from 1897 to 1904, and invited one of his then subordinates, Namihei Odaira ${ }^{4}$, who had by this time become manager of the Power Transmission Section of the Tokyo Electric Light Co., Ltd., to become manager of the Electrical Sub-section at the Hitachi Mine. In 1908 Odaira established a workshop for the repair of the Hitachi Mine's electrical machinery. However, not content with simply repairing electrical machinery, in 1910 he turned his hand to its manufacture. His next step was to branch out from the manufacture of electrical machinery for use in the Hitachi mine alone, and to start manufacturing to fill orders from outside the mine. This step is regarded as the establishment of the Hitachi Manufacturing Plant, which went on to be incorporated as a joint-stock company in 1920 .

This paper will consider the questions of why Kuhara, owner-

Hideyoshi Toyotomi to Yoshinobu Satake, the Lord of Hitachi Province (modern Ibaraki Prefecture) to develop a gold mine. In 1602 Satake became Lord of Dewa Province (modern Akita Prefecture). He was replaced as Lord of Hitachi by a member of the Tokugawa family, and the development of the mine languished. However, in a list of copper mines in a document dating from about 1700 the name 'Akazawa' does appear. It seems, therefore, that the development of the mine was not entirely abandoned.

The real development of the Akazawa Copper Mine did not start until 1901, when it was purchased by Boies \& Co., and renamed the Akazawa Mining Co., Ltd. Boies \& Co. was run by Richard Boies, a German whose base of operations was Yokohama.

Until Fusanosuke Kuhara took it over in 1905, Akazawa Copper Mine had been managed by a Norwegian named Olsen. He was born in Bergen in 1837, and had a Japanese wife and one daughter. He spoke some Japanese, and was trusted by the mineworkers and others.

In 1904 one Shinroku Ōhashi appears in the records of the Akazawa Mining Co., Ltd. as Sole Mining Agent, and it was he who signed the contract with Fusanosuke Kuhara when the latter purchased the mine. (Minoru Kaya, Hitachi kōzan shi [History of the Hitachi Mine] (Nippon Mining Co., Ltd., 1952), and Denki (cited above in Note 2).

4. Concerning Namihei Odaira see, for example: (1) Odaira Namihei Kinenkai, eds., Odaira-san no omoide [Recollections of Mr. Odaira] (Odaira Namihei Kinenkai, 1952); (2) Saizō Kanami, Jūkōgyōōo odaira namihei [Namihei Odaira - king of heavy industry] (Ryūgaisha, 1939); (3) Tsutomu Fujita, Nihon no denki kōgyō wo kizuita hito - odaira namihei-ō no shōgai [The Life of Namihei Odaira - the man who built Japan's electrical Industry] (Tokyo: Kokuseisha, 1962); Izawa Hisasa, Hitachi ichigō e no shūnen -odaira namihei no jigyō to hito [Tenacious commitment to Hitachi's first product - Namihei Odaira and his business undertakings], (Tokyo: Sōzōsha, 1967). 
manager of Fujitagumi \& Co., went independent and established Kuhara Mining, and why the Hitachi Manufacturing Plant was spun of from Kuhara Mining.

\section{KUHARA GOES INDEPENDENT FROM FUJITAGUMI \& CO.}

Fujitagumi \& Co. was one of the best-known large enterprises in prewar Japan. It had been established by Denzaburō Fujita in 1870, who was joined in its management in 1872 by his two elder brothers Shikatarō Fujita and Shōzaburō Kuhara. It developed thereafter under the joint management of the three brothers.

In Japan in 1889, if we exclude banks, there existed 19 corporations with a capital of $¥ 500,000$ or more ${ }^{5}$. These included a total of 6 companies under the Fujita umbrella - Fujitagumi \& Co. itself, and 5 subsidiaries. In 1916, Heitarō Fujita, who had assumed the Presidency of Fujitagumi \& Co. in 1912, was ranked 5th in the list of the wealthiest men in Japan ${ }^{6}$. The company was eventually to collapse as a result of the 1927 financial crisis.

Around 1897 Fujita and Co. faced a management crisis. Over the period 1894-95 its President, Denzaburō Fujita, suffered losses of approximately one million yen as a result of speculation in shares ${ }^{7}$. In 1896, moreover, their main business, the Kosaka Mine ${ }^{8}$, had virtually

5. Naosuke Takamura, Kaisha no tanjō [The birth of the company] (Tokyo, Yoshikawa Kōbunkan, 1996), p.78.

6. Jiji Shinpōsha, ed., Zenkoku gojūman-en ijō shisanka-hyō [List of persons in Japan with assets of $¥ 500,000$ and above] (Tokyo: Jiji Shinpōsha, 1916)

7. Dowa Mining Co., Ltd., ed., Fujita-ke kiroku (Fujita Denzaburō jiden) [Record of the Fujita family (autobiography of Denzaburō Fujita)] (Denzaburō Fujita's words recorded by Reisaku Nishimura).

(Recollections spoken by Fujita and recorded by his his secretary [his cousin] Nishimura around 1910. These were typed up in the early nineteen-fifties as part of the editing work for the Dowa Mining Company's history 70-nen no kaiko [Looking back over 70 years], and bound in a limited edition in the early nineteen-eighties as part of the editorial materials for the company history Sögyō hyaku-nen shi [History of the century since our foundation]).

8. Concerning the Kosaka Mine see, for example (1) Dowa Mining Co., Ltd., ed., 70nen no kaiko [Looking back over 70 years] (Dowa Mining Co., Ltd.,1955); (2) Dowa Mining Co., Ltd., ed., Sōgyō hyaku-nenshi [History of the century since our foundation] (Dowa Mining Co., Ltd., 1985); (3) Hidetatsu Satoh, "Fujitagumi no sandō jigyō" [The copper production business of the Fujitagumi \& Co. during the first quarter of the 
ceased to be profitable. Also, in connection with the Kojima Bay Reclamation Project ${ }^{9}$, for which planning had started in 1882, they had expended approximately one million yen in trying to placate local opinion and on lobbying politicians and government officials. Despite this, however, there was a fierce campaign of opposition, and no progress had been made. All these factors combined to push Fujitagumi $\&$ Co. to the very brink of bankruptcy.

The core business of the Kosaka Mine had originally been the smelting and refining of silver. When Kuhara became Office Manager in 1897, he over to copper smelting and refining, and by $1900 \mathrm{had}$ developed new technology for this purpose. In the five-year period from 1906 to 1910 the Kosaka Mine posted profits of $¥ 15.9$ million $^{10}$.

twentieth century], Aichi sangyō daigaku kiyō [Bulletin of Aichi Sangyo University], 11, 2003.

9. Concerning the Kojima Bay reclamation Project see (1) Kojima-wan Kaikon Jimusho, ed., Kojima-wan kaikonshi [History of the reclamation of Kojima Bay] (Kojima-wan Kaikon Jimusho, 1902); (2) Tsuneshige Inoue, Kojima-wan kaikonshi [History of the reclamation of Kojima Bay], (Kanao Bun'endō, 1902) ; (3) Tsuneshige Inoue, Teisei zōho kojima-wan kaikon shi [History of the reclamation of Kojima Bay, revised and enlarged], (Okajima Shoten, 1903); (4) Seiichi Maeda, Fujita nōjō keieishi [History of the management of the Fujita farm] (Nihon Bunkyō Shuppan, 1965); (5) Keita Inoue, Kojima-wan kantaku shiryō shüshūroku [Gathering materials for the history of the reclamation of Kojima Bay] (Dowa Mining Co., Ltd., 1967); (6) Kojima-ko Hattatsushi Hensan'iinkai [Committee for the compilation of the history of the development of Kojima Bay], ed., Kojima-ko Hattatsushi [History of the development of Kojima Bay] (Kojima-ko Kankei Dantai Kinen Jigyō Kyōsankai, 1972); (7) Kojima-ko Hattatsushi Hensan'iinkai [Committee for the compilation of the history of the development of Kojima Bay], ed., Kojima-ko Hattatsushi - zoku [History of the development of Kojima Bay - continued] (Kojima-ko Kankei Dantai Kinen Jigyō Kyōsankai, 1977); (8) Moritarō Ōyama, Nihon nōgyō seisanryoku dankai to chūkaku nōminso no gainen [Stages in the development of agricultural production capacity in Japan and the concept of the intermediate farming class] (Tochi Seido Shiryō Hozonkai, 1954); (9) Yasuo Kondō, "Fujita nōjō no seiritsu to hōkai" [The establishment and collapse of the Fujita farm] (Rikkyō University, Keizaigaku kenkyū, 13, No. 4, 1959); and (10) Hidetatsu Satoh, "Fujitagumi ni yoru Kojima-wan kantaku jigyō" [The Kojima Bay Reclamation Project by Fujitagumi \& Co.] (Aichi Sangyo University College Bulletin, No. 11, 1998).

10. Letter from Fusanosuke Kuhara to Kaoru Inoue dated January 30, 1912 (In the "Kaoru Inoue documents" held in the Costitutional Materials Room of the National Diet Library) An outline of this letter appears in Dōwa kōgyō shashi Tanaka Sōgorō-sensei shippitsu sōkō senzen-hen [Draft manuscript by Prof. Sōgorō Tanaka for the prewar section of the Dowa Mining Co. company history] (1953), pp. 158-9. (Hereafter referred to as $S \bar{o} k \bar{o}$.) 
Permission to start work on the Kojima Bay Reclamation Project was received in 1898 , thanks to the efforts of Hikoichi Motoyama ${ }^{11}$, the General Manager of Fujitagumi \& Co., and in 1902 the reclamation of the main sections was completed.

By 1902, thanks to the resurgence of the Kosaka Mine and the progress of the Kojima Bay Reclamation Project, the fortunes of Fujitagumi \& Co. had been reestablished, and from about this time Denzaburō Fujita started thinking about his successor. Shikatarō, one of the joint managers of Fujitagumi \& Co., had died in 1896, and his son, Kotarō Fujita, had joined the management team. Shōzaburō, one of the other joint managers, had retired in 1905 , to be replaced by his son, Fusanosuke Kuhara. Denzaburō had three sons, Heitarō, Tokujirō, and Hikosaburō.

The profits earned thanks to the resurgence of the Kosaka Mine were considerable, and Fusanosuke's standing within the company was high. Denzaburō was well aware that if he were to choose his successor on the basis of managerial ability the choice would be Fusanosuke. However, Denzaburō tried to designate his eldest son, Heitarō, as his successor. In the background to this issue lay the fact that despite the fact that Denjirō had been the youngest among his siblings, he had continued to run Fujitagumi \& Co. as President, thanks to the policy of putting ability above other considerations.

A struggle started over the succession between Denjirō, the current President, and Fusanosuke, who wished to succeed him in that post. Denzaburō came to a decision that if he could not get agreement on

11. Concerning Hikoichi Motoyama see, for example (1) Riichirō Araki, ed., Kōhon motoyama hikoichi-ō den [Draft biography of Hikoichi Motoyama] (Osaka, Osaka Mainichi Shinbunsha, 1929); (2) Ko-Motoyama Shachō Denki Hensan Iinkai [Editorial committee for the biography of the late President Motoyama], ed., Shoin motoyama hikoichi-ō [Hikoichi Motoyama] (Osaka Mainichi Shinbunsha and Tokyo Nichinichi Shinbunsha, 1937); (3) Ko-Motoyama Shachō Denki Hensan Iinkai [Editorial committee for the biography of the late President Motoyama], ed., Shōin motoyama hikoichi-ō ikō [Posthumous manuscripts of Hikoichi Motoyama] (Osaka Mainichi Shinbunsha and Tokyo Nichinichi Shinbunsha, 1937); and (4) Hidetatsu Satoh, "Motoyama Hikoichi ron" [On Hikoichi Motoyama] (Jissen Keiei Gakkai, Kansai jissen keiei [Kansai Journal of Applied Management], No.29, 2005).

Motoyama's wife, Kiku, was Fusanosuke Kuhara's younger sister. Between 1806 and 1906 Motoyama served as Manager and General Manager of Fujita \& Co., and from 1903 to 1932 as President of the Osaka Mainichi Newspaper. 
Heitarō as his successor, that the three should all become independent and separate. Bluntly put, he had made the decision to force Kotarō and Fusanosuke out of Fujitagumi \& Co. ${ }^{12}$.

The year 1905 was spent fighting this power struggle. In summer of that year it was finally decided that Kotarō and Fusanosuke would leave Fujitagumi \& Co., and go independent.

During September and October 1905 it was decided, at Denzaburō's request, that Kaoru Inoue, a major political figure in Japan at the time, who was also highly influential in the business world, would act as arbitrator to decide on the distribution of funds to the two men who were to become independent. Inoue had Denzaburō, Kotarō, and Fusanosuke hand him formal letters of agreement that they would raise no objection to his decision. Inoue valued the assets of Fujitagumi \& Co. at $¥ 18,920,000$, and proposed that Kotarō and Fusanosuke would each receive $25 \%$ of this figure - a sum proportional to their investment. This came to $¥ 4,730,000$ to each of them, to be paid in annual installments over a period of 10 years ${ }^{13}$. These sums were paid from the accounts of Fujitagumi \& Co. from 1906 through 1915.

Prior to this arbitration decision Fusanosuke had argued, unsuccessfully, that it would not be unreasonable to value the assets of Fujita \& Co. as high as $¥ 40$ million, but that he would be willing to set the figure at $¥ 24$ million, and accept $25 \%$ of this, namely $¥ 6$ million $^{14}$. Out of consideration for Fusanosuke's dissatisfaction with the arbitration, Inoue arranged for the Mitsui Bank to furnish Fusanosuke with a loan of $¥ 4.5$ million, on the security of his share of the fund allocation from Fujitagumi \& Co. ${ }^{15}$.

In 1903 Denjirō agreed with Inoue and Tarō Katsura, an influential political figure, that he would at some time in the future accept Katsura's son Yoichi into Fujitagumi \& Co., and treat him on the same terms as his own sons Heitarō, Tokujirō, and Hikosaburōo ${ }^{16}$.

In December 1905, immediately after his departure from Fujitagumi

12. Sōkō, p.157.

13. Ibid., p.159.

14. Ibid., pp. 158,159.

15. Denki, p.336.

16. Hidetatsu Satoh, "Fujitagumi no senmon keieisha" [On the Professional Manager of the Fujitagumi \& Co.] (Aichi Sangyo University College Bulletin, No. 10, 1997.) 
\& Co., Fusanosuke purchased the Akazawa Copper Mine for $¥ 300,000$. In September of that year he had sent Kuranojō Takeda, a mining engineer at the Kosaka Mine, to evaluate the Akazawa Copper Mine. The timing is uncertain, but Korehiko Takeuchi, a smelting and refining specialist at the Kosaka Mine, also went to the Akazawa Copper Mine for the same purpose ${ }^{17}$.

Fusanosuke and Denzaburō had been in dispute over a number of issues: whether the next proprietor of Fujitagumi \& Co. should be Heitarō or Fusanosuke; whether Fusanosuke would become proprietor of the Kosaka Mine should he leave Fujitagumi \& Co. and go independent; and if the ownership of the Kosaka Mine was not to go to Fusanosuke, what recompense he would receive in its stead. At the same time, there was also the question of what type of business Fusanosuke would engage in should he leave Fujitagumi and Co.

Fusanosuke's departure from Fujitagumi \& Co., was not of his own free will, but was a result of his defeat in the struggle over the succession to Denzaburō as President of Fujitagumi \& Co. It was, in fact, a type of restructuring.

Immediately after his purchase of the Akazawa Copper Mine Fusanosuke changed its name to the Hitachi Mine, taking the name from Hitachi Village in Ibaraki Prefecture, where the mine was located. Thereafter, a custom was established whereby the mines of the Kuhara Mining Co. were named after their location.

\section{THE HITACHI MINE OF THE KUHARA MINING CO.}

By 1912, seven years after Fusanosuke's departure from Fujitagumi and Co. to take over operation of the Hitachi Mine, more than 40 of the technical staff of the Kosaka Mine had left there, and taken up jobs at the Hitachi Mine ${ }^{18}$. The non-manual employees of the Kosaka Mine in the period 1910-1912, including office staff, numbered between 147 and $181^{19}$. This is evidence of the high degree of trust placed by Kosaka

17. Minoru Kaya, op. cit., p.68

18. Dowa Mining Co., Ltd., ed., 70-nen no kaiko, op.cit., p.53.

19. Hidetatsu Satoh, "Fujitagumi no shokuin" [On the Career of the Staff at the Kosaka Mine in the early 1910s] (Aichi Sangyo University College Bulletin, No. 7, 1994), p.22. The original sources are materials held in the General Affairs Section of the 
Mine staff in their former Office Manager, Fusanosuke.

In 1905, the Kuhara Mining Co. was not a corporation, but Kuhara's personal business undertaking. The establishment of the Kuhara Mining Co., Ltd. Took place in October 1912, with a capital of $¥ 10$ million and 114 shareholders. From its foundation until the outbreak of World War I the sole major business undertaking of the Kuhara Mining Co. (both before and after its incorporation) was the Hitachi Mine.

At the time of its establishment the Kuhara Mining Co. obtained finance not only from the Mitsui Bank, but also from the Kōnoike Bank. As a condition of this financing, the Kōnoike Bank sent a technical expert, Reiji Kanda, to be General Manager of the Hitachi Mine. When Kanda took up his post he brought with him a large number of technical staff, but there was continual conflict between Kuhara, who wished to invest further in order to develop the mine, and Kanda, whose concern was the preservation of the value of its assets. As a result, Kanda resigned his post in 1907, along with the technical staff who had accompanied him ${ }^{20}$.

To replace these technicians Kuhara gathered together staff from the Kosaka Mine, where he had previously been employed as Office Manager.

At the beginning of 1906 the Hitachi mine, under the overall control of Kuhara, was organized into four functional departments: mining, smelting, engineering and general affairs. After Kanda took up his post

Kosaka Mine of the Dowa Mining Co., Ltd.: "Shoin rireki shirabe - meiji 43nen 11 gatsu genzai" [Survey of officers careers - as of November 1910], "Kosaka kōzan yakuin rireki shirabe - meiji 43nen 4gatsu 15nichi genzai" [Survey of careers of Kosaka Mine officers - as of April 15, 1911], and "Kosaka kōzan yakuin rireki shirabe - shochōshitsu-yō (meiji 45nen 7gatsu 31nichi teisei)" [Survey of careers of Kosaka Mine officers - for Manager's Office use (revised July 31, 1912)].

20. Minoru Kaya, op. cit., pp.73-74.

Reiji Kanda was born in 1858, the eldest son of Yōjirō Kanda of Gifu Prefecture. In 1882 he graduated from the Higher Engineering College.

Kanda and his colleagues had been employed at a mine managed by the Mōri family, and when the family withdrew from mine management they lost their jobs. This was one of the reasons for their taking up employment at the Kosaka Mine.

Concerning Reiji Kanda see, for example, Teikoku daigaku shusshin jinmei jiten [Biographical dictionary of graduates from the Imperial University] reproduced by Nihon Tosho Center based on Hajime Katsuta, ed., Teikoku daigaku shusshin meikan [Biographies of graduates of the Imperial University] (Kōyū Chōsakai, 1932), vol.1, 2003, pp.526-7. 
as General Manager in May 1906, an analysis department was added. Next, in November of that year there was a further reorganization into 8 departments: mining, smelting, engineering, electrical, general affairs, accounting, purchasing and medical. Then, in July 1907, under the new General Manager who had come from the Kosaka Mine, four Sections were established: the Engineering Section, the Mining Section, the General Affairs Section and the Smelting and Refining Section. Both the General Manager and the managers of all the Sections were transferees from the Kosaka Mine.

Once Kuhara had taken over as proprietor of the Hitachi mine, he built a large-scale smelting and refining plant on the mine premises. The capacity of this plant was too great to be satisfied by the output of ore from the Hitachi Mine alone. The value of metal product produced by the Hitachi Mine in 1909 totaled $¥ 523,873$, of which $22.5 \%$ was from the sale of metal smelted and refined from ore purchased from outside. By 1912 these figures had risen to $¥ 6,857,816$ and $44.7 \%$ respectively. The increase in sales income is impressive, but it is clear too that the proportion of ore purchased externally had also risen sharply ${ }^{21}$.

The first external purchases of ore by the Hitachi Mine were in 1907, from the Hanaoka Mine (in Akita Prefecture; purchased by Fujitagumi \& Co. in 1915) and the Nishizawa Mine (in Tochigi Prefecture). By 1908 the number of sources exceeded 30, including the Innai Mine in Akita Prefecture.

At that time, the majority of mines in Japan processed only their own ore; the Kosaka Mine was the only one to be smelting and refining externally-purchased ore on a large scale. The Hitachi Mine had now started the smelting and refining of bought-in ore on an even larger scale than the Kosaka Mine. The development of the Kuhara Mining Co. was due less to the purchase of the high-quality large-scale Hitachi Mine, than to the construction of a large smelting and refining plant, with the mine as its basis.

After purchasing the Akazawa Mine in 1905, between 1906 and 1912 Kuhara set about reorganizing the mining operations at his mines. He

21. "Dai 7hyō meiji makki nenbetsu, jizanbetsu, baikōde hanbaidaka taihihyō" [Table 7: comparison of sales of ore by year and by mine in the late Meiji period] in Minoru Kaya, op.cit., p.120. 
also constructed smelting and refining facilities, electricity generating plant, an on-site railroad, and a private railway line between the Hitachi Mine and the nearest National Railway station at Sukegawa. Although the actual figures are not available, it is clear that Kuhara spent more on constructing the smelting and refining plant and organizing the infrastructure of the Hitachi Mine with electricity generating plant, railroads, etc., than he had invested in the mine itself.

In Kuhara's memoirs, he recalls the management of the Hitachi Mine as being 'full of trials and tribulations. ${ }^{22}$,

At the time of the reorganization of the Kuhara Mining Co. into the Kuhara Mining Co., Ltd. in 1912, the sales of the Hitachi Mine (virtually identical to the total annual sales income of the Kuhara Mining Co.) amounted to over $¥ 6,850,000$. The value of its copper production was the third highest in Japan, after Furukawa \& Co. and Fujitagumi \& Co. Set against its capital of $¥ 10$ million, however, its sales figure of $¥ 6,850,000$ was relatively low.

\section{FROM ELECTRICAL REPAIR SHOP TO MANUFACTURING PLANT}

Namihei Odaira had graduated from the Electrical Engineering Department of the Faculty of Engineering of Tokyo Imperial University in 1900. On graduation he joined Fujita \& Co. and worked for three years and four months at the Kosaka Mine. His first job at the Kosaka Mine had been to design and supervise the construction of a $500 \mathrm{KW}$ hydroelectric generating plant. This plant went into operation in 1902. He was also involved in the design and construction of transformer stations and of electric railroads and electric lighting facilities within the mine.

After this, after employment with the Hiroshima Hydroelectric Power Company (the present-day Chugoku Electric Power Co., Inc.), he worked as Head of the Power Transmission Section of the Tokyo Electric Lighting Company (the present-day Tokyo Electric Power Co., Inc. $)^{23}$.

22. Denki, pp.357-365. Concerning this point see also Masaru Udagawa, "Nissan zaibatsu keisei katei no keieishiteki kōsatsu" [A consideration of the development of the Nissan zaibatsu from the perspective of business history] (Keiei shigaku, 6, No. 3, 1970).

23 . Concerning general trends in the early Japanese electric power generation industry 
In October 1906 Odaira changed jobs and became head of the Electrical Sub-Section at the Hitachi Mine. His main role at the Tokyo Electric Lighting Company had been to act as interpreter, conveying to the Japanese craftsmen the instructions of the engineers from GE and other companies who had come to supervise the installation of powergeneration and transformer. Odaira had not been content with a mere interpreting role, and wished to be personally involved in the manufacture of electrical equipment; it was this that impelled him to change employment. This decision to change jobs, from the head of a Section at the power company that supplied electricity to the Japanese capital, Tokyo, and its environs, to be head of a Sub-Section at a mine which had only just started operations, is not one that most people would consider rational ${ }^{24}$. At this time, Kuhara, owner-manager of the Hitachi Mine, had no thought whatsoever of engaging in the manufacture of electrical machinery.

From being head of the Electrical Sub-Section Odaira became head of the Engineering Section. The head of this Section was responsible for supervising the design, construction and setting up of virtually all equipment and facilities required by the mine: civil engineering work, the construction of buildings for the smelting and refining plant, the construction of the electric power plant and transformer and power transmission facilities, and the laying of the mine's internal railroad, and the railroad track connecting the mine to the nearby National Railway line. In practice he had overall responsibility for the whole technical support operations of the mine.

As an electrical engineer, one of Odaira's tasks was the construction of power generation facilities. Within 5 months of his appointment he

see Tetsurō Watari, Senzenki no wagakuni denryoku dokusentai [On the monopolistic structure of the Japanese electric power industry in the prewar period] (Shōyō Shobō, 1996), pp.2-3, 8-9. This work, however, makes no mention whatsoever of the internal power generation facilities of mines and other enterprises.

24. Motoharu Shibusawa, "Preface", to Toshio Hasegawa, Hitachi seisakushoshi [The history of the Hitachi factory] (Hitachi Hyōronsha, 1949), pp.3-7.

For a brief outline of the establishment and development of the Hitachi Factory under Odaira, see Bijuaru nihon keieishi [A visual business history of Japan] (Maruzen Audiovisual Library "Nihon no kigyōka gunzō dai5-kan gijutsu shikō-gata jigyō tenkai to shijō-gata seichō" [Portaits of Japan's entrepreneurs; Vol. 5, The development of technically-oriented business and market-oriented growth] (Series editor: Takao Shiba) (Tokyo, Maruzen, 2000). 
had completed a $300 \mathrm{KW}$ power plant, which started producing electricity in March 1907. In 1908 and 1909 he added respectively a $200 \mathrm{Kw}$ and a $300 \mathrm{KW}$ plant. In 1911, the 3000KW Ishioka Power Station - at that time the largest hydroelectric power plant in Japan went into operation.

The development of Odaira's activities at the Hitachi Mine can be roughly divided up into the following categories: 1) Power generation, begun to supply the mine's needs for electric power; 2) Electrochemical processes such as carbide manufacture, begun to utilize excess electric power capacity; and 3) Electrical machinery manufacturing. This paper is primarily concerned with the third category - electrical machinery manufacture at the Hitachi Plant of the Hitachi Manufacturing Plant.

In 1908 Odaira set up an electrical machinery repair shop. This was on an extremely small scale, with 5 workers in a building of about 130 $\mathrm{m}^{2}$. In the following year, 1909, it still only employed 11 workers. The miners at the Hitachi Mine treated their equipment very harshly; wear on electrical equipment was particularly severe, and repairs were constantly required.

In March 1910 this repair shop produced three 5hp electric motors. These products can be said to mark the birth of the Hitachi Manufacturing Plant.

At the beginning of 1910 Odaira persuaded Kuhara to agree to the inclusion of $¥ 90,000$ for the construction of an electrical machinery manufacturing plant in the budget for the expansion of the electrical repair shop.

In November 1911, an electric equipment manufacturing plant (the present-day Hitachi Factory) was established, comprising 4,181 $\mathrm{m}^{2}$ of buildings on a site of over $13,200 \mathrm{~m}^{2}$. To reduce costs, the buildings were of wooden construction, and built with logs rather than with squared timber. The plant employed 33 white-collar staff (including sales and accounts personnel as well as technicians) and 360 blue-collar workers.

In the early days the electric motors and other electrical equipment that the plant manufactured were inferior to the products of American and European firms such as Westinghouse and Siemens, and faults were frequent. Odaira was later to recall that even though an electric motor 
was expected to rotate, the early ones failed to do so, and he even contemplated abandoning their manufacture ${ }^{25}$. There were strong demands from the Hitachi Mine that they be allowed to use the products of Western manufacturers rather than those from this plant. The Mine also objected vociferously to their continued production of electrical equipment.

Kuhara, the Mine's proprietor, felt that machinery of high quality should be used, even though it was more expensive ${ }^{26}$, and in the early days the Mine did not order electrical machinery from their own manufacturing plant. But since profits from the Hitachi Mine were considerable, Kuhara felt that there was enough leeway for them to use the products of this plant, and instructed that in the case of small electric motors the firm's own products were to be used.

Among the first products of the manufacturing plant were five 1000kVA transformers for the Ishioka Power Plant, under construction at that time; these were completed in June 1906. In Japan at the time GE had an overwhelmingly large share of the supply of power station equipment, with Japanese products hardly being used. Quite apart from its status as Japan's largest power station, the Ishioka Power Station was of major importance for the manufacture of large-scale electrical equipment such as transformers. Its significance was not restricted simply to the Hitachi Manufacturing Plant, but extended to the Japanese electrical engineering industry as a whole. Apart from this, the Manufacturing Plant produced a large number of 10-20hp motors for the Hitachi Mine, and gradually began to receive orders for electrical equipment from power stations and other enterprises throughout Japan.

In 1912 the Manufacturing Plant built a 275hp electric motor for the Hitachi Mine. From this time on, products were given a serial number, and this $275 \mathrm{hp}$ motor was embossed with Serial No. 1.

25. Tsutomu Fujita, op.cit., pp. 214-215.

26. See Masanori Yoshida, "Senzen ni okeru wagakuni denki sangyō no kigyōsha katsudō - odaira namihei wo chūshin ni" [The activities of entrepreneurs in the prewar Japanese electrical engineering industry - with particular reference to Namihei Odaira] (Mita shōgaku kenkȳū, 22, No.5, 1979). 


\section{THE BIRTH OF THE HITACHI FACTORY}

In December 1911 the electrical equipment manufacturing activities of the Hitachi Mine were moved from the purview of the Engineering Section, to become a separate division of the Kuhara Mining Co., paralleling its mining activities, under the new title of the Hitachi Factory.

The decade from 1910 onwards saw great prosperity for the Factory due to the cessation of imports of electrical equipment from Europe and America as a result of World War I, but in the periods immediately before and after this, business conditions were far from good.

In its early days the Factory suffered from numerous problems, with delivery delays arising from inadequate equipment, inexperience, and the poor quality of Japanese raw materials.

In 1914, for example, the Factory built a 200,000 volt transformer for its own use. The largest capacity transformer that it had built to date had been one 50,000 volts. Great care was devoted to its design, but the finished product failed to work. Investigation revealed that the direction of the internal windings had mistakenly been reversed, so that the polarity of the terminals was opposite to that intended.

An oil circuit breaker delivered in 1915 to the Inawashiro Hydroelectric Company exploded violently immediately after its installation. This circuit breaker was for use on a $36,000 \mathrm{KW}$ power line, and should have had an appropriately large circuit-breaking capacity. In fact, however, what had been delivered was a standard circuit breaker designed for use on 6,000 volt power lines. Both the customer and the producer should have been aware of the situation, but there was a lack of technical expertise on both sides.

In 1916 an accident occurred where the cast steel end plates, used to restrain the bushes of a $2200 \mathrm{kVA}$ generator buckled, destroying the generator. This accident was a result of a lack of mechanical rather than electrical knowledge.

In the same year the Factory received an order from the Ministry of Communications Electrical Research Institute for a 350,000 volt experimental transformer. A transformer of the compound-filled ceramic bushing type was designed and manufactured, and tests were 
carried out at the Ministry of Communications in the presence of inspectors in April 1917. At 320,000 volts the transformer discharged. Technicians were summoned to replace the compound, but the repairs did not go smoothly at first, and it was not until November that the transformer finally passed the Ministry inspection.

In 1917 the Factory manufactured a 400hp 3600rpm induction motor, but the end cover split during testing, because they had made an error in the choice of materials, using a home-made bronze-like alloy (90\% copper, $10 \%$ tin), instead of the nickel steel that they should have used but were unable to obtain. They had of course carried out careful strength calculations, and believed that they had left sufficient margin for error as far as strength was concerned. They had also carried out high-pressure water tests, but their testing methods had been inappropriate.

In the decade after 1910 the Hitachi Factory experienced a large number of failures in the manufacture of electrical machinery ${ }^{27}$. One of the reasons was that inexperienced engineers, newly graduated from university, were designing on the basis of textbook knowledge alone. Another was the scarcity of suitable raw materials during wartime, as well as delays in the delivery of the necessary raw materials and parts. But the process of remedying their failures enabled the engineers of the Hitachi Factory to accumulate know-how in the manufacture of electrical machinery.

Not everything that the Hitachi Factory manufactured during this period was a failure. In 1915 the Tone Electric Power Company ordered a turbine from the Factory to replace one that it had ordered from Hoit in Germany, but which could not be delivered because of the war. With its casing and cover the weight of this turbine was close to 30 tons. The most powerful crane in the Hitachi Factory had a capacity of only 7.5 tons, causing major problems in moving the turbine to enable water pressure testing. This turbine was designed with a very large margin for error, so the final product - at $10,000 \mathrm{hp}(7,000 \mathrm{~kW})$ was considerably more powerful than the order from the Tone Electric Power Company specified. The largest capacity generator orders that the Hitachi Factory had filled hitherto were for $100 \mathrm{hp}$ spiral and $1,240 \mathrm{hp}$ Pelton turbines.

27. Toshio Hasegawa, op.cit., pp.50-55. 
This was the first time that a $10,000 \mathrm{hp}$ generator had been built anywhere in Japan. The Factory received follow-up orders from the Tone Electric Power Company for a further two turbines.

So, learning from its failures, the early days of the Hitachi Factory saw considerable development, particularly in the manufacture of largescale electrical machinery.

In 1907 the Kuhara Mining Co. established The Tsukudajima Works at Tsukudajima in Tokyo, as a branch factory of its Engineering Section. The Tsukudajima Works developed from doing repair work for the Hitachi Mine into the manufacture of machinery, but remained a smallscale facility. In 1912 the Tsukudajima Works purchased the Kunitomo Works at Shiba, Tokyo, which became the Shiba Branch Factory. This factory manufactured pumps and hoists.

Because the Tsukudajima Works was extremely cramped, it moved in 1916 to Kameido, also in Tokyo. 50 workers moved to Kameido from Tsukudajima, and a further 30 from the Shiba factory; further workers were employed, bringing the total workforce at Kameido to 250 . In 1918 the Tsukudajima Works, now relocated in Kameido, merged with the Hitachi Factory, and became its Kameido Works, while the Hitachi Factory was restyled the Hitachi Works.

The Tsukudajima Works was a general engineering plant, manufacturing such products as turbines, pumps, cranes, hoists, air blowers and compressors. After it became the Kamedo Works of Hitachi Manufacturing, it took over from the Hitachi Works the manufacture of turbines for hydroelectric power generation.

On the instructions of its owner-manager, Fusanosuke Kuhara, in 1921 the Hitachi Factory purchased the Kasato Shipyard of the Nihon Steamship Co., Ltd., a firm already under the Kuhara umbrella. After serious consideration as to how the Kasato Shipyard could best be used, Odaira renamed it the Kasato Works, and converted it to the manufacture of steam locomotives. The nineteen-twenties saw an electrification boom in the Japanese railway industry, and the Kasato Works consequently developed into a major facility for the manufacture of electric locomotives.

From the nineteen-twenties onwards Hitachi, Ltd. had developed into a comprehensive electrical and mechanical engineering manufacturing enterprise, with three major production facilities. It built large 
generators and other electrical machinery at its Hitachi Works (Ibaraki Prefecture), general machinery at its Kamedo Works (Tokyo), and electric locomotives and other railway equipment at its Kasato Works (Yamaguchi Prefecture) $^{28}$.

That customers for electrical equipment, such as electric companies and mines, placed orders with the Hitachi Factory was primarily for rational commercial reasons, though on occasion, in the early days, there were cases where the person responsible for placing the order was a graduate of Odaira's alma mater, the Electrical Engineering Department of Tokyo Imperial University, and took the risk of placing the order in order to support Odaira's business ${ }^{29}$.

Odaira's guiding principles were: 'The Japanese must manufacture products in no way inferior to foreign imports,' and 'Technology and marketing are the two essential components of a manufacturing enterprise.' It was on the basis of these principles that he undertook the manufacture of electrical equipment ${ }^{30}$.

\section{THE BACKGROUND TO THE INCORPORATION OF THE HITACHI FACTORY}

In 1920 the Hitachi Factory was reorganized as a joint-stock company. The reasons for this change are unclear.

As a result of the stagnation in the non-ferrous metal business that accompanied the end of World War I, the business performance of the Kuhara Mining Co. deteriorated sharply. Simultaneously, Siemens and

28. Concerning the Hitachi Works see Hitachi Seisakusho Hitachi Kōjō [Hitachi, Ltd., Hitachi Works], ed. and publ. Hitachi kōjō 70nenshi [70-year history of the Hitachi Works] (1985); for the Kameido Works see Shizuka Asano, ed., Kameido Kōjō 50nen no ayumi [50-year history of the Kamedo Works] (Hitachi Seisakusho Kameido Kōjō, 1960); and for the Kasato Works see Hitachi Seisakusho Kasato Kōjō [Hitachi, Ltd., Kasato Works], ed. and publ., Hitachi Seisakusho Kasato Kōjōshi [History of the Kasato Works of Hitachi, Ltd.] (1975).

29. Tsutomu Fujita, op.cit., pp.213-214.

It is said that Takasuke Okamoto, Chief Engineer at the Nagoya Electric Lighting Company, who attended the University 7 years before Odaira, took pity on him when the Hitachi Factory's reputation was low, and ordered a large motor from the desperate Odaira.

30. Masaru Udagawa, "Odaira Namihei” [Namihei Odaira], in Nihon dai hyakka zensho [Comprehensive encylopedia of Japan] (DVD-ROM version, Super Nipponica 2003, Shogakukan). 
Westinghouse started a low-price attack on the Japanese market, and Japanese electrical equipment manufacturers were forced to accept orders at prices which did not cover their production costs. The future development of the Hitachi Factory seemed in doubt, and Odaira himself considered prospects for the company's future to be 'gloomy. ${ }^{31}$,

From the beginning of 1918 Odaira had been considering the incorporation of the Hitachi Factory, and in January 1919 his ideas on this subject were conveyed to Kuhara. Kuhara felt that if the Factory was to be managed separately as a joint-stock company, it would be best to tie up with a powerful foreign electrical equipment maker. So, in September that year Kuhara began to plan a link with Siemens Hursk.

However, Odaira opposed the introduction of foreign technology, and wanted to develop the Hitachi Factory using Japanese technology. Further, Siemens itself was hesitant about forming such a link.

At a meeting of managers of businesses in the Kuhara group in January 1920 Odaira proposed that the Hitachi Factory should become independent. In this he received the support of Takeuchi, whose position in the Kuhara organization was second after Kuhara himself ${ }^{32}$.

To Odaira, Kuhara was a businessman whose principal commitment was to achieving high profits by exploiting a high-quality mine, and saw his other businesses in the same way, as no more than speculative ventures. He lacked the will, Odaira felt, to build up the business in a steady fashion. And, in fact, if Kuhara saw a prospect of earning big profits he had no hesitation in diversifying his businesses, with no thought for any synergy between them from either a marketing or a technical viewpoint. Odaira's policy, on the other hand, was to expand the business soundly, in a way which utilized their technical synergy. It would appear that Odaira was keen that Kuhara should be involved as little as possible in the management of the Hitachi Factory and its manufacture of electrical equipment.

When the Hitachi Factory was turned into a joint-stock company in 1920 the post of President was left vacant, a fact not unrelated to the above issue. It is likely that Odaira was unwilling for Kuhara to occupy

31. Masanori Yoshida, op.cit., p.57. (The original source is "Odaira Namihei-ō denki shiryō" [Materials for the Biography of Namihei Odaira], held in the Head Office of Hitachi, Ltd..)

32. ibid., pp. 56-58. 
this post. Conversely, Kuhara was probably unwilling for Odaira to become President, thus placing him beyond Kuhara's control. Takeuchi was essentially a smelting and refining engineer, unsuited to the responsibility of running an electrical equipment manufacturing business. So, at this point in time, it would appear that a compromise was reached whereby the President's post in the new company was left vacant, while Odaira held the post of Managing Director and in practice managed the business.

In 1929 Odaira assumed the post of President of Hitachi Ltd., which had remained vacant since the incorporation of the company. In 1928, the year after the financial crisis of 1927, it became clear that the Kuhara Mining Company and Kuhara's other business ventures were effectively bankrupt. Kuhara, their proprietor, withdrew from their management, to be succeeded by Yoshisuke Aikawa, who undertook the reconstruction of the company ${ }^{33}$. We could say that the financial crisis on the one hand triggered the restructuring of Kuhara's businesses, and on the other enabled Odaira to become President of Hitachi, Ltd.

The development of the Hitachi Factory owes more to the entrepreneurship of Odaira, the professional manager, than it does to either its owner-proprietor Kuhara, or to Aikawa. Odaira pursued the goal of independent operation for the Factory, sometimes clashing and sometimes compromising with Kuhara and Aikawa concerning how the business should be managed. He rejected Kuhara's arguments for a link with an overseas electrical equipment manufacturer, insisting on autonomous and independent management. In the matter of the appointment of company officers also, Odaira pushed through his own views.

In order to preserve the autonomy of Hitachi, Ltd., Odaira held down the level of dividends, retaining internally as much profit as possible. He even went so far as to refuse requests from the company's owner for the provision of funds.

Odaira, the professional manager, succeeded in developing Hitachi, Ltd. as a professionally managed enterprise ${ }^{34}$.

33. Concerning this point see Kazuyoshi Yamazaki, op.cit., pp.194-195.

34. Nobuhisa Fujita, "Odaira Namihei" [Namihei Odaira] in Keieishi Gakkai [Business History Society of Japan], ed., Nihon keieishi no kiso chishiki [Basic knowledge on Japanese business history] (Tokyo: Yūhikaku, 2004), p.222. 


\section{CONCLUSION}

The establishment of the Kuhara Mining Co., Ltd. stems from the determination of Denzaburō Fujita, founder and President of Fujitagumi $\&$ Co., that he should be succeeded by his eldest son. Denzabuō was well aware that Fusanosuke Kuhara commanded great respect and trust within Fujitagumi and Co., and that if ability was to be the criterion Fusanosuke was the obvious choice as next President. Because Denzaburō wished to designate his eldest son, Heitarō, as next President for reasons other than ability, a power struggle ensued. As a result of this power struggle Fusanosuke departed from Fujitagumi \& Co., and commenced the management of his own enterprise, the Kuhara Mining Co. Seen from the viewpoint of the management structure of Fujita \& Co., this was a form of restructuring.

The Kuhara Mining Co. still exists as Japan Energy (strictly speaking, as its holding company Nippon Mining Holdings, Inc.) and has also been the fountainhead that gave rise to a large number of enterprises such as the Nissan Motor Corporation, Hitachi, Ltd., and the Hitachi Zosen Corporation.

Hitachi, Ltd., originated in the wish of Fusanosuke Kuhara, who had just begun to manage the Kuhara Mining Co., to obtain the services of a capable electrical engineer. He sent for Namihei Odaira, who had experience in power station construction and similar work when he had been Fusanosuke's subordinate in Fujitagumi \& Co. Odaira, dissatisfied with his position as a middle manager in a large electric power company, was keen to be directly involved in the manufacture of electrical equipment. With this ambition in his mind, he accepted a post at the Kuhara Mining Co., which was no more than a fledgling mining enterprise.

Odaira's role at the Kuhara Mining Co. ranged widely, from civil engineering and building, through machinery installation to power station construction, and as part of this he established an electrical repair

For more detailed information on this point see Masaru Udagawa, "Hitachi seisakusho ni okeru ōnā to senmon keieisha" [The owner and the professional manager in Hitachi, Ltd.], in Hidemasa Morikawa, ed., Keieisha kigyō no jidai [The age of the professionallymanaged enterprise] (Tokyo, Yuhikaku, 1991). 
shop which he progressively developed into a factory for the manufacture of electrical equipment. Having first established this electrical equipment factory as the Hitachi Factory, standing alongside the Hitachi Mine within the Kuhara Mining Co., he then proceeded to develop it into Hitachi, Ltd., an independent all-round electrical engineering manufacturer. In terms of business organization, this can also be seen as a restructuring process, in the sense that an integrated electrical manufacturing enterprise was created from out of a mining business.

Looking at the process as a whole, we can see that the foundation of the Kuhara Mining Co. was a result of a power struggle within the top management of Fujitagumi \& Co., over the succession to the leadership of that company. The foundation of Hitachi, Ltd. was the culmination of the ambition of Namihei Odaira, a mere electrical engineer, to become and independent manufacturer of electrical equipment.

Although the foundation of both these companies would appear to be similar in that they both represent spin-offs from existing enterprises, in terms of their significance they are completely different.

Walt W. Rostow identifies the periods from 1878 to 1900 or from 1900 to 1920 as the economic 'take-off' of Japan ${ }^{35}$. In this latter period both Fusanosuke Kuhara and Namihei Odaira identified business opportunities, and though they were active in the separate fields of mining and electrical equipment manufacture, they both succeeded in building up major enterprises. In this sense they can both be regarded as outstanding entrepreneurs.

35. W.W. Rostow, The Stages of Economic Growth - A Non-Communist Manifesto (Cambridge University Press, 1960), pp.36-40.

In Japanese historical circles, Japan's industrial revolution is generally accepted to have taken place between 1886 and 1907.

Rostow's discussion is based on a number of premisses, and uses econometric tools and a range of historical statistics. It is extremely interesting to consider the difference between Rostow's two alternative 'take-off' periods, 1878 to 1900 and 1900 to 1920 , and the received wisdom among Japanese historians that Japan's industrial revolution took place in the period from 1886 to 1907. 